\title{
Teaching Content on Social Work Practice with Religious Congregations: A Curriculum Module
}

\author{
Michael Sherr \\ Terry Wolfer
}

\begin{abstract}
Thispilotstudy representsan effort to implement and evaluate useof a curriculum module on Charitable Choice and social work practice in a faith-based organization. Using a nonequivalent control group design, repeated measures MANOVA showed significant differences between the treatment $(n=54)$ and comparison groups $(n=53)$ on knowledge and degreof comfort at posttest. Despitetheuse of a small sample $(n=107)$ of MSW students at a public university in the Southeast, the findings provideinitial support for further useand futureevaluations of curriculum modules covering specific content on practice in faith-based settings.
\end{abstract}

Keywords: Religion, congregations, case, macro, practice, education

U ntil the end of the $19^{\text {th }}$ century, religious congregations and the organizations they spawned were virtually the sole providers of social services in the United States (Cnaan, 1999; Garland, Hugen, Myers, Sheridan, Sherwood \& Wolfer, 2002; Salamon \& Teitelbaum, 1984; Wineburg, 2001). The social work profession itself emerged out of the efforts of "friendly visitors" and founders of settlement houses, both of which worked under the auspices of congregational outreach. Congregations and their volunteers founded relief agencies, children's homes, recreation services, family and children associations, and mental health associations. In other words, religiously motivated volunteers preceded social work in almost every field of practice (Anderson \& Ambrosino, 1992; Forte, 1997; Sherr, 2003).

Despite social work's origins, the nascent profession quickly embraced the scientific method in the early 1900s, spawning eight decades of social services largely disconnected from religious traditions. As the delivery of services became more systematic and social work became increasingly secular, religious congregations and other faith-based organizations (FBOs) silently continued providing a hidden safety net of services (Cnaan, 1999). Nevertheless, the role of congregations and their volunteers became increasingly marginalized and virtually ignored by the social work profession (Garland, et al., 2002).

Michael Sherr is Assistant Professor at the School of Social Work, Northwest Nazarine University, Nampa, Idaho 83686 and Terry Wolfer is associate professor at the College of Social Work, University of South Carolina, Columbia, SC 29208.

Copyright $^{\oplus} 2004$ Advances in Social Work Vol. 5 No. 2 (Fall 2004) 197-210.

Indiana University School of Social Work. 
Since 1980, several converging factors have created a contemporary urgency for social work educators to prepare students for practice with faith-based organizations (FBOs). Over his two terms in office, President Reagan set forth a devolutionary era in social welfare policy that continues to this day. Then in 1996, Democrat and Republican leaders officially welcomed FBOs into the circle of service providers by including Charitable Choice in section $\S 104$ of the Personal Responsibility and Work Opportunity Reconciliation Act of 1996 (Castelli \& McCarthy, 1998; Devita, Printz \& Towombly, 1999; Sherman, 2000; Wineburg, 2001). More recently, in the 2000 Presidential election, both Al Gore and George W. Bush endorsed expanding the role of FBOs as major components of their social welfare strategy. Shortly after his inauguration, President Bush announced the formation of the White House Office of Faith-Based and Community Initiatives. Today, Charitable Choice and FBOs continue garnering bipartisan support as some on the Right see an opportunity "to cut public spending while maintaining a spirit of care," while some on the Left see a way "to circumvent bureaucratic administration of publicly funded services" (Cnaan \& Boddie, 2002, p. 229).

\section{BACKGROUND LITERATURE}

Social work practice in FBOs may involve working with social systems ranging from large religiously affiliated international organizations to local religious congregations (Cnaan, Wineburg \& Boddie, 1999). Of these, local congregations are by far the most numerous and widely dispersed in American society (Wolfer \& Sherr, 2003). For this study, congregations can be defined simply as "local gatherings [of people] for religious purposes" (Harris, 1998, p. 602).

While no one knows exactly, there are more than 150 million people in American congregations (Linder, 2001). Roughly one third of people attend services weekly, another third occasionally, and one third attend rarely or not at all (Hodgkinson, Weitzman \& Kirsh, 1990; see also Holifield, 1994). The total number of congregations in the United States range from a low of 200,000 to a high of 450,000 (Ammerman, 2001; Boddie, et al., 2001; Dudley \& Roozen, 2001). By various counts, American congregations also represent more than 200 denominations (Cnaan, et al., 1999, p. 28) or nearly 1600 denominations (Warner, 1994, p. 58). Although the size of congregations vary considerably, more than half of the congregations in the United States have 100 to 400 members (Linder, 2001).

Typically, congregations have linkages to larger FBOs. In fact, they usually provide the base of support for larger FBOs in terms of both finances and personnel. Congregations also provide a variety of social services on their own. In the two most thorough assessments to date, Chavez, Konieczny, Beyerlein and Barman (1999) estimate that $57 \%$ of congregations offer at least one social service program, and Boddie, et al., (2001) estimate that $87 \%$ of congregations offer at least one social service program.

From a systems perspective, congregations are likely the first level of FBOs students will interact with in their professional practice. On one hand, students may work with individuals, groups, and families who are members of congregations. On the other hand, they may work with congregations themselves as community 
organizations. Regardless of the level of practice, students must be prepared for competent practice with these macro level systems.

\section{SOCIAL WORK'S RESPONSE TO RELIGIOUS CONGREGATIONS AND THEIR SOCIAL PROGRAMS}

Until recently, social work scholars have tended to overlook the role of religious congregations in people's lives (Wolfer \& Sherr, 2003). This is ironic given the social work profession's ecological and social systems perspectives. Commenting on the absence of interest, Wineburg (2001) laments:

The academic community skipped by the most dramatic shift in public policy in more than half a century... [And if the academic community is going to become effectively involved] it will be difficult without an overarching analysis of the impact of the service contributions the people in these 300,000 congregations make, with their organizational arms reaching both inward to help their own members and outward to support sectarian and secular agencies in the nonprofit sector (p. 40).

In the last several years, however, social work literature has given limited but increasing attention to religion and religious congregations. Research on religion has focused primarily on the notion of religious beliefs as a tool for practitioners to use in building rapport with clients for whom religion is an important issue (Cnaan, Wineburg \& Boddie, 1999). Furthermore, only a handful of studies exist on religious congregations as organizations providing social programs. While such studies are laudable efforts, they are primarily descriptive, with findings that are difficult to interpret. After a review of the literature, Wolfer and Sherr (2003) conclude, "the American religious world is decentralized in the extreme.... [Because of the difficulty in locating good sampling frames], it is difficult if not impossible to measure the various aspects of congregational life" (p. 44). Despite the methodological difficulties, there is growing consensus among social work scholars that: 1 ) the efforts of religious congregations are greater than previously imagined; 2) there is a lot more to learn; and 3) social workers, if informed about Charitable Choice initiatives and the willingness of many religious congregations to provide social services, can participate and provide leadership in coordinating partnerships with congregations to deliver effective service programs (e.g., Garland, 1992, 1998; Garland, et al., 2002; Cnaan, et al., 1999; Sherman, 2000).

\section{EFFORTSTO PREPARE STUDENTS AND PRACTITIONERS}

In light of the current context, efforts to incorporate content about religion, congregations, and Charitable Choice into the social work curriculum have been distressingly slow. In fact, recent research on social work education and religion reveals that the profession is still primarily assessing the place of religion in the curriculum (Casio, 1999; Kaplan \& Dziegielewski, 1999; Sheridan \& Hemert, 1999; Staral, 1999). The authors posit that the time for assessing the place of such content has passed and a new era of social welfare requires attention.

A few scholars offer different approaches for preparing students to practice with FBOs. Most notably, Loewenberg (1988) provides an overview of the history of religion within society, Netting, et al. (1990) describe integrating religious content 
into the macro practice curricula, and Canda (1989) presents a comparative approach for integrating religious content into the HBSE curricula. More recently, Furman (2002) makes recommendations for schools of social work that want to infuse religious and spiritual diversity throughout the entire curriculum, and $\mathrm{Ai}$ (2002) endorses a multidisciplinary approach that covers an array of different theoretical and conceptual perspectives. Finally, Sherwood, Wolfer and Scales (2002) suggest using decision cases for infusing spirituality and religion content into the classroom.

Although each of the approaches represent innovative and laudable efforts to provide resources for social work educators, further research is needed to examine how to implement and evaluate teaching methods for integrating religious content in the curriculum. This study outlines an initial effort to implement and evaluate use of a curriculum module on Charitable Choice and social work practice in a faith-based organization. Specifically, it addresses the question: How will a module on social work practice in faith-based organizations affect students' knowledge about and comfort with such practice?

\section{METHODS AND PROCEDURE}

Given the above information, the authors developed, administered, and evaluated a curriculum module on Charitable Choice and religious congregations in six sections of a foundation level MSW macro practice course. The decision to introduce the module to students in a foundation macro practice course was prompted by the author's agreeing with Netting, et al. (1990) that: "Understanding local congregations and their enmeshment within the social service delivery system is important to any social work practitioner who hopes to effect community change" (p. 22).

\section{The Curriculum Module}

The module consisted of four components: a journal article reading, didactic instruction, small group work, and decision case discussion. The first component covered the basic provisions of Charitable Choice law. Charitable Choice has far reaching implications for social work practice as it opens the door for collaboration between religious organizations and public services. In a recent article, Cnaan and Boddie (2002) explain that having a basic understanding of the law will lay "a foundation for considering the implications for social work practice, education, and research" (p. 225).

In advance of the class session, the authors provided students with copies of a journal article and a decision case to read in preparation for the class session. The article assessed the potential benefits and challenges of Charitable Choice. More specifically, it discussed Charitable Choice in the current political context, the contradictory and limited research on implementation of the law, and encouraged social workers to attend to these developments (Cnaan $\&$ Bodie, 2002). The decision case highlighted the experiences of a licensed clinical social worker who was solicited by a church leader to meet with a family that had come to their church for help. What began as a one-time occurrence, eventually led to a decision about whether and how to advocate for systematic changes in the congregation's community outreach (author citation for published case). 
Decision cases differ from the types of cases most often used in social work education. Merseth (1996) refers to the traditional type of cases as examples or exemplars. These cases depict practice situations with (usually) appropriate responses and serve to illustrate the application of theory or professional skill in concrete situations. In contrast, decision cases present students with dilemmas encountered by social workers in their professional practice. These cases provide explicit opportunities for students to practice making decisions and contemplate possible interventions. More than exemplars, decision cases present the complexities and ambiguities of actual social work practice (Sherwood, Wolfer \& Scales 2002). Sherwood, et al. (2002) explain:

Rather than simply critique a professional's behavior, [decision] cases require that students use their analytic and critical thinking skills, their knowledge of social work theory and research, and their common sense and collective wisdom to identify and analyze problems, to evaluate possible solutions, and to formulate a preferred intervention (p. 5).

Borrowing from Carlson-Thies (2001), the authors' also created a one-page handout that covers the purpose of Charitable Choice (available from the first author). The handout specified how Charitable Choice attempts to: 1 ) encourage more States to contract with FBOs; 2) protect the unique character of religious organizations; 3) protect the religious freedom of potential beneficiaries; and 4) maintain separation of church and state. For instance, states that contract with any nonprofit organization must give FBOs an equal opportunity to compete for funding. Charitable Choice also affirms that FBOs can display religious symbols, use faith-based approaches in providing services, and can use religious criteria in staffing the programs. The religious freedom of recipients are protected by ensuring that alternative services are available for recipients who object to religious providers and affirms that recipients are not required to participate in religious activity as a precondition for receiving services. Finally, separation of church and state is maintained by requiring that government funds only be used for providing public service and not for inherently religious practices such as worship, Sunday school, or proselytization.

After a brief lecture on the basic purposes of Charitable Choice, students were divided into small groups of six to eight. Each group reviewed a specific section of the Cnaan and Boddie (2002) article. One group reported on the political evolution of Charitable Choice. They discussed how the law, although initially supported by Conservatives, now claims bipartisan support. They also discussed how the law remains controversial and is currently being challenged in state and federal court. The next group discussed the findings of several studies mentioned in the article. For instance, the group shared how few clergy were even aware that Charitable Choice existed. They also conveyed how slowly Charitable Choice was being implemented among most states. The last group summarized Cnaan and Boddie's call for social workers to carefully follow the implementation process of Charitable Choice to assess the potential benefits and consequences of the law.

The final component of the module was a class discussion of The Grace House Ministry (author citation) - the decision case specifically written for the module. 
The case had several twists and turns that worked as step off points for examining social work practice with religious congregations. During the course of the class discussion, students were given opportunities to reflect upon practice issues such as: confidentiality, self-determination, dual relationships with clients (as both a member of a congregation and a social worker), and balancing a congregation's desire to provide needed services while respecting the specific characteristics of the congregation that may or may not conflict with social work values. Towards the end of the case discussion, students were prompted to consider two interrelated questions: 1) How close was the congregation to securing Charitable Choice funding? and 2) What concrete steps should the congregation take in order to receive funding?

The entire curriculum module required approximately 90 minutes of class time. The approximate timetable for each component was as follows:

- 10 minutes for reviewing the basic purposes of Charitable Choice;

- 20 minutes for meeting in small groups to discuss and summarize three sections of the journal article (Cnaan \& Boddie, 2002); and

- 60 minutes for the decision case discussion.

\section{Research Design}

Using a quasi-experimental design, a convenience sample of MSW students was selected for the study. Students registered for one of six sections of a foundation level MSW macro practice course. A total of 116 MSW students enrolled in the six sections; however, nine students were not present at the posttest and were excluded from the study. After all students registered, three of the sections were randomly assigned as treatment groups $(n=54,50.5 \%)$ and three sections were randomly assigned as comparison groups ( $n=53,49.5 \%)$. The six sections met once a week from 9 A.M. to 12 noon. Three sections met on Tuesday, the other three on Wednesday.

To minimize contamination from selection bias and to account for the Hawthorne effect, the first author handled all phases of implementing the curriculum module and administering the survey instruments to each of the sections at pretest and posttest. During the first three weeks of the Fall 2002 semester, the survey instrument was administered for pretest. The survey was re-administered for posttest at least six weeks after each pretest. This allowed enough time inbetween measurements to reduce the possibility of any testing effects that might occur from filling out the same survey.

Students in both the comparison and treatment groups covered the standard material on FBOs within the context of ontological communities (Brueggemann, 2002) with their assigned instructors. Students in the comparison group were administered posttests after covering the normal course material. Students in the treatment group were administered posttests after covering the standard course material and the curriculum module. At the request of instructors, the first author presented the curriculum module to students in the comparison group after data was collected. 


\section{Survey Instrument}

The survey, which was designed specifically for this study (see appendix), asked students to indicate their level of agreement on a scale of 1 (strongly disagree) to 4 (strongly agree) for a list of 10 different statements. The 10 statements comprised two subscales intended to measure students' knowledge of Charitable Choice and their degree of comfort working with religious congregations. A total score was calculated for each scale at pretest and posttest. Higher scores on the knowledge scale indicated better comprehension of the governing rules of Charitable Choice. Higher scores on the second scale indicated a greater degree of comfort working with religious congregations. Four additional questions asked for demographics—sex, age, ethnicity, and how often students attended worship services during the past year.

The survey was found to have an internal consistency of .81 ( $n=116)$. According to Nunnally (1978), this level of reliability is adequate for basic research. Although the survey appears to have face validity, efforts to establish more dependable measures of validity were beyond the scope of this study.

It was hypothesized that students enrolled in the sections comprising the treatment group would differ significantly from those in the comparison group in: 1) their increased knowledge of the governing rules of Charitable Choice; and 2) their increased comfort working with religious congregations.

\section{Data Analysis}

Data analysis consisted of three stages. In stage one, the data were entered and checked for entry errors, missing data, and outliers. All entry errors were corrected; the missing data consisted of only the nine excluded cases, and there were no extreme values on any single variable. In stage two, frequency distributions and chi-square analyses were used to examine the distribution of demographic categories between treatment and comparison groups. Finally, repeated-measures MANOVA was performed to assess the overall affects of the curriculum module over time, the overall difference between treatment and comparison groups over time, and the individual differences in knowledge and degree of comfort scores between the two groups over time.

\section{FINDINGS}

\section{Demographic Characteristics}

Table 1 presents the distribution of selected demographic characteristics of the 107 respondents by treatment and comparison groups. As the table reveals, there are no significant differences between the treatment and comparison groups in terms of ethnicity and frequency of attending worship services during the last year. There was, however, a significant difference between the two groups in terms of age. Although a majority of the respondents in both groups are age 20 to 29 , more than $80 \%(81.1 \%, n=44)$ of the respondents in the treatment group are age 20 to 29 , while only two-thirds $(66 \%, n=35)$ of the respondents in the comparison group are age 20 to 29. Moreover, less than $6 \%(5.6 \%, n=3)$ of the respondents in the treatment group are age 30 to 39 , while more than $20 \%(22.6 \%, n=12)$ of the respondents in the comparison group are age 30 to 39 . Respondents age 40 and older appear evenly distributed between the two groups. 


\begin{tabular}{|c|c|c|c|}
\hline & $\begin{array}{l}\text { Treatment Group } \\
(n=54)\end{array}$ & $\begin{array}{c}\text { Comparison Group } \\
(n=53)\end{array}$ & \\
\hline Variable & n (\%) & $\mathrm{n}(\%)$ & Significance \\
\hline Gender & & & no analysis \\
\hline Male & $1(1.9)$ & $7(13.2)$ & \\
\hline Female & $53(98.1)$ & $46(86.8)$ & \\
\hline Ethnicity & & & nonsignificant \\
\hline Anglo American & $34(63.0)$ & 36 (67.9) & \\
\hline African American & $17(31.5)$ & $11(20.8)$ & \\
\hline Other & $3(5.5)$ & $6(11.3)$ & \\
\hline Age & & & $\chi^{2}=6.49, \mathrm{df}=2$ \\
\hline 20 to 29 & 44 (81.5) & $35(66.0)$ & $p=039$ \\
\hline 30 to 39 & $3(5.6)$ & $12(22.6)$ & \\
\hline 40 and older & $7(6.6)$ & $6(11.3)$ & \\
\hline \multicolumn{4}{|l|}{$\begin{array}{l}\text { Frequency of } \\
\text { attending worship } \\
\text { services during }\end{array}$} \\
\hline & & & nonsignificant \\
\hline $\begin{array}{l}\text { Twice a year and } \\
\text { less }\end{array}$ & $14(25.9)$ & $10(18.9)$ & \\
\hline $\begin{array}{l}\text { Once a month to } \\
\text { twice a year }\end{array}$ & $17(31.5)$ & $16(30.2)$ & \\
\hline $\begin{array}{l}\text { Two or three times } \\
\text { a month }\end{array}$ & $6(11.1)$ & $9(17.0)$ & \\
\hline Every week & $17(31.5)$ & $18(34.0)$ & \\
\hline
\end{tabular}

Table 1 also reveals that female students represent a large majority of the respondents in both groups. Male students, however, represent $13.2 \%(n=7)$ of the comparison group and $1.9 \%(n=1)$ of the treatment group. Chi-square analysis could not be completed since the treatment group had less than five males. The differences in age and gender reflect enrollment trends in this social work education program. However, the small sample and the preliminary nature of the study preclude further inferences.

\section{Outcome Measures}

As noted previously, repeated measures MANOVA was performed to assess whether the overall effects of the curriculum module resulted in significant changes over time. Wilks' Lambda $(F(2,104)=13.35, p<05)$ allows the null hypothesis to be rejected. Thus, overall significant changes were discovered from pretest to posttest. Likewise, Wilks' Lambda $(F(2,104)=7.30, p<05)$ indicates overall significant differences between the treatment and comparison groups.

Table 2 depicts measures of the treatment and comparison groups at pretest and posttest. The means of the two groups at pretest were similar for both dependent measures. At posttest, the findings reveal a significant difference in knowledge measures between the two groups. Although knowledge scores were higher for both groups at posttest, students exposed to the curriculum module 
Table 2: Measures of Knowledge and Degree of Comfort with MANOVA of Posttest Scores

\begin{tabular}{|lclllc|}
\hline & \multicolumn{2}{c}{ Pretest } & \multicolumn{2}{c}{ Posttest } & F Test of \\
Measure & Treatment & Comparison & Treatment & Comparison & Posttest \\
Score
\end{tabular}

${ }^{\oplus} \mathrm{p}<.05 .{ }^{\oplus} \mathrm{p}<.01$.

scored significantly higher than students in the comparison group. In the same way, the findings reveal a significant difference in the degree of comfort measures between the two groups. Here again, students exposed to the curriculum module report a greater degree of comfort working with religious congregations compared to students in the comparison group. Interestingly, the posttest scores for the degree of comfort for students in the comparison group were marginally lower than at pretest.

\section{DISCUSSION}

The findings from this study must be interpreted with caution. The use of a small convenience sample of students as well as a nonstandardized instrument limits their generalizability. Furthermore, although data analysis reveals statistically significant differences in the hypothesized direction, the amount of improvement remains unclear. Conclusions regarding the practical development in knowledge about Charitable Choice or the degree of comfort working with religious congregations is not warranted. As an initial effort to implement and evaluate a curriculum module, however, this study begins to fill the need for empirical studies on teaching social work practice with FBOs.

\section{Knowledge and Degree of Comfort}

The curriculum module received preliminary support from this study. Although knowledge subscale scores increased for both groups, only the scores in the treatment group were significantly higher at posttest. Similarly, students in the treatment group reported a higher degree of comfort in working with religious congregations. Similar to knowledge scores, however, only students in the treatment group reported higher degrees of comfort working with religious congregations at posttest. The degree of comfort scores was actually lower for students in the comparison group at posttest.

The lower scores related to the degree of comfort subscale for students in the comparison group was an anomalous finding. At first glance, the authors' expected that after completing a foundation level macro practice course, students would feel more comfortable working with all types of communities and organizations, including religious service providers. In hindsight, however, the authors suggest that it may be necessary to present specific material on religious providers as legitimate places for social work practice. Otherwise, students may never recognize their newly acquired knowledge and skills as relevant for working with FBOs. 


\section{CONCLUSION}

The current module, with its emphasis on religious congregations as potential partners in delivering effective service programs, is ideally suited for courses focusing on organization and community development. Additional innovative modules on religion and spirituality need to be developed and implemented in other courses, including HBSE, social policy, and practice with individuals, groups, and families. More importantly, however, the efficacy of this and other approaches needs to be empirically evaluated. That being said, this study provides preliminary support for using the current module for teaching social work practice with religious congregations in a foundation macro practice course.

\section{References.}

Ammerman, N.T. (2001). Doing good in American communities: Congregations and service organizations working together (research report). Hartford, CT: Hartford Seminary, Hartford Institute for Religious Research.

Anderson, S.C., \& Ambrosino, R.N. (1992). Should volunteers be used as direct service givers? In E. Gambrill \& R. Pruger (Eds.), Controversial issues in social work (pp. 174-175). Boston: Allyn \& Bacon.

Ai, A.L. (2002). Integrating spirituality into professional education: A challenging but feasible task. Journal of Teaching in Social Work, 22(1/2), 103-130.

Boddie, S.C., Cnaan, R.A., \& Dilulio, J.J. (2001) Philadelphia census of congregations and their involvement in social service delivery: Methodological challenges and findings (unpublished manuscript). Philadelphia, PA: University of Pennsylvania.

Brueggemann, W.G. (2002). The Practice of Macro Social Work. Belmont, CA: Brooks/ Cole.

Canda, E.R. (1989). Religious content in social work education: A comparative approach. Journal of Social Work Education, 25, 36-45.

Carlson-Thies, S. (2001). Charitable Choice 101: An introduction. Retrieved October 1, 2002, from: http:// downloads.weblogger.com/gems/cpj/319.pdf.

Casio, T. (1999). Religion and spirituality: Diversity issues for the future. Journal of Multicultural Social Work, 7, 129-145.

Castelli, J., \& McCarthy, J.D. (1998). Religion-sponsored social services: The not-so-independent sector. Available: http://members.aol.com/jimcast/aspfn97.htm [1999, August 17].

Chavez, M., Konieczny, M.E., Beyerlein, K., \& Barman, E. (1999). The National Congregations Study: Background, methods, and selected results. Journal for theScientific Study of Religion, 38(4), 458-476.

Cnaan, R.A. (1999). Our hidden safety net. Brookings Review, 17, 50-53.

Cnaan, R.A., Wineburg, R.S., \& Boddie, S.C. (1999). The newer deal: Social work and religion in partnership. New York: Columbia University Press.

Cnaan, R.A., \& Boddie, S.C. (2002). Charitablechoice and faith-based welfare: A call for social work. Social Work, 47(3), 224-235.

Devita, C.J., Printz, T.J., \& Towombly, E.C. (1999). Report to the human services faith-based organizations task force Washington, D.C.: Urban Institute.

Dudley, C.S., \& Roozen, D.A. (2001). Faith communities today: A report on religion in the United States today (research report). Hartford, CT: Hartford Seminary, Hartford Institute for Religion Research.

Forte, J.A. (1997). Calling students to serve the homeless: A project to promote altruism and community service. Journal of Social Work Education, 33, 151-166. 
Furman, L.D. (2002). Recommendations for infusing religious and spiritual diversity throughout the social work curriculum. Paper presented at the North American Association of Christians in Social Work Convention, Rochester, NY.

Harris, M. (1998). A special case of voluntary associations? Towards a theory of congregational organization. The British Journal of Sociology, 49(4), 602-618.

Hodgkinson, V.A., Weitzman, M.S., \& Kirsch, A.D. (1990). From commitment to action: How religious involvement affects giving and volunteering. In R. Wuthnow \& V.A. Hodgkinson \& Associates (Eds.), Faith and philanthropy in America: Exploring the role of religion in America's voluntary sector (pp. 931140). San Francisco: Jossey-Bass.

Hollifield, J.A. (1987). Towards a history of American congregations. In J.P. Wind \& J.W. Lewis (Eds.), American Congregations (Vol. 2, pp. 23-53). Chicago: The University of Chicago Press.

Garland, D.R. (Ed.). (1992). Church social work. St. Davids, PA: North American Association of Christians in Social Work.

Garland, D.R. (1998). Church social work. In Beryl Hugen (Ed.), Christianity and social work: Readings on the integration of Christian faith and social work practice (pp. 7-25). Botsford, CT: North American Association of Christians in Social Work.

Garland, D.R., Hugen, B., Myers, D., Sheridan, P., Sherwood, D., \&Wolfer, T.A. (2001). Effective leadership of faith-motivated volunteers in community service programs. Paper presented at the annual program meeting of the Council on Social Work Education, Nashville, TN.

Kaplan, A.J ., \& Dzeigielewski, S.F. (1999). Graduate social work students' attitudes and behaviors toward spirituality and religion: Issues for education and practice. Social Work and Christianity, 26, 25-39.

Linder, E.W. (Ed.). (2001). Yearbook of American \& Canadian churches 2001 (Vol. 69). Nashville, TN: Abingdon Press.

Loewenberg, F.M., (1988). Religion and social work practicein contemporary American society. New York: Columbia University Press.

Netting, F.E., Thibault, J.M., \& Ellor, J.W. (1990). Integrating content on organized religion into macropractice courses. Journal of Social Work Education, 26, 15-26.

Nunnally, J.C. (1978). Psychometric theory. New York: McGraw-Hill Book Company.

Salamon, L.M., \& Teitelbaum (1984). Religious congregations as social service agencies: How extensive are they? Foundation News, 62-65.

Scales, T.A., Wolfer, T.A., Sherwood, D.A., Garland, D.R., Hugen, B., \& Pittman, S.W. (2002). Spirituality and religion in social work practice: Decision cases with teaching notes. Alexandria, VA: CSWE.

Sheridan, M.J., \& Hemert, K.A. (1999). The role of religion and spirituality in social work education and practice: A survey of student views and experiences. Journal of Social Work Education, 35, 125-141.

Sherman, A. (2000). Should we put faith in charitable choice? The Responsive Community, 10(4), 22-39.

Sherr, M.E. (2003). Infusing volunteerism into the HBSE curriculum of MSW programs. Arête, 27, 81-87.

Sherr, M.E., \&Wolfer, T.A. (2003). Preparing social work students for practice with religious congregations within the context of charitable choice: The grace house ministry (A). Social Work and Christianity, $30(2), 128-148$.

Sherwood, D., Wolfer, T.A., \& Scales, L.T. (2002). Introduction: Spirituality and religion, decision cases, and competent social work practice. In T. Laine Scales, Terry A. Wolfer, David Sherwood, Diana Garland, Beryl Hugen, \& Sharon Pittman (Eds.), Spirituality and religion in social work: A sourcebook of decision cases. Alexandria, VA: CSWE.

Staral, J.M. (1999). Seeking religion and spiritual competence: The perceptions of BSW students at a private, Catholic university. Social Work and Christianity, 26, 101-111.

Warner, R.S. (1994). The place of the congregation in the contemporary American religious configuration. In J.P. Wind \& J.W. Lewis (Eds.), American congregations (Vol. 2, pp. 54-99). Chicago: The University of Chicago Press.

Wineburg, R.S. (2001). A limited partnership: Thepolitics of religion, welfare, and social service. New York: Columbia University Press. 
Wolfer, T.A., \& Sherr, M.E. (2003). American congregations and their social programs. In T. Tirrito \& T. Casio (Eds.), Religious organizations in community services (pp. 23-50). New York: Springer.

\section{Author's Note:}

Address correspondence to: Michael Sherr, Assistant Professor, School of Social Work, Northwest Nazarine University, 623 Holly Street, Nampa, Idaho 83686, USA. E-mail: mesherr@nnu.edu 


\section{Appendix}

\section{Student Questionnaire on Social Service Programs and Policies}

Please take a few minutes to respond to each item by indicating whether or not you agree with the following statements. Your participation is completely voluntary. However, if you decide to participate, be assured that your responses are strictly confidential. Please do not write your name anywhere on the questionnaire as we wish to keep your responses anonymous.

Please mark an $\mathrm{X}$ or $\mathrm{a} \checkmark$ in the box indicating the extent to which you agree with the following statements. Please mark only one box per question.

\section{Knowledge}

1. "Charitable Choice" is a provision designed by the federal government to encourage more religious congregations to offer social service programs.

2. "Charitable Choice" permits a religious congregation to require clients to participate in worship ceremonies in order to receive social services.

3. Social service programs offered by religious congregations primarily serve members of the same congregation.

4. "Charitable Choice" permits a religious congregation to receive government funds to help the poor.

5 "Charitable Choice" allows a religious congregation to display religious art, scripture, religious apparel, and other symbols while delivering social service programs.

\section{Degree of Comfort}

6. I would be willing to refer clients to a social program provided by a religious congregation.

7. I would be willing to collaborate with a religious congregation to develop a social program for my clients.

8. I would be willing to receive services from a social program provided by a religious congregation.

\section{Strongly Agree Disagree Strongly Agree}

[ ]

[ ]

[ ]

[ ]

[

[ ] [ ]

[ ]

[ ] [ ] [ ]

[ ]

[ ] [ ]

[ ]

[ ]

[ ]

[ ]

[ ]

[ ] [ ]

[ ]

[ ]

[ ] [ ]

[ ] 


\begin{tabular}{|c|c|c|c|c|}
\hline \multicolumn{5}{|c|}{ Appendix (cont.) } \\
\hline \multicolumn{5}{|c|}{ Student Questionnaire on Social Service Programs and Policies } \\
\hline Degree of Comfort (cont.) & Strongly & Agree & Disagree & Strongly \\
\hline $\begin{array}{l}\text { 9. Social workers should be willing to } \\
\text { work for a social service program run } \\
\text { by a religious congregation. }\end{array}$ & $\begin{array}{c}\text { Agree } \\
\text { [ ] }\end{array}$ & [ ] & [ ] & $\begin{array}{c}\text { Disagree } \\
\text { [ ] }\end{array}$ \\
\hline $\begin{array}{l}\text { 10. I would be willing to work for a social } \\
\text { service program run by a religious } \\
\text { congregation. }\end{array}$ & [ ] & [ ] & [ ] & [ ] \\
\hline
\end{tabular}

